\title{
Evaluation of Thyroid Hormone Levels in Females with Dysfunctional Uterine Bleeding
}

\author{
Mohamed M. El-Meligui ${ }^{1}$; Dawlat A. El-Miligy ${ }^{2}$; Abdel-Hamid \\ M.Attia ${ }^{1}$; Omima E.Hassan ${ }^{3 ;}$ Neemat H.Youssef ${ }^{1}$ and Ahmed El- \\ Demery $^{4}$ \\ Obstetric \& Gynecology ${ }^{1}$; Medical Biochemistry ${ }^{2}$ and Pathology ${ }^{3}$ \\ Departments ; Faculty of Medicine; Cairo University and Medical \\ Biochemistry ${ }^{4}$ Department October 6 University.
}

\begin{abstract}
Abnormal uterine bleeding is one of the most frequent gynecologic problems. About $80 \%$ of abnormal uterine bleeding are due to hormonal disorders and are called dysfunctional uterine bleeding (DUB). TSH and thyroid hormones dysfunction in women can influence the ovarian cycles by many ways. They can interfere with follicular stimulating hormone (FSH), luteinizing hormone (LH), peripheral metabolism of different steroid hormones, prolactin as well as the metabolism of sex hormone binding globulins ( $S H B G)$.

The aim of the present study is to evaluate the functional status of thyroid gland in apparently euthyroid women with abnormal menstruation. Three groups of age matched female subjects were studied. Group I included 20 women with menorrhagia, group II comprised 20 women with oligo, hypo or oligo-hypomenorrhea and group III included 20 women with normal menstruation as a control group.

Serum TSH, total and free T3\&T4, FSH, LH, prolactin, progesterone total and free testosterone were evaluated to all subjects of the study.

The results of the present study showed that there was a significant increase in serum total T3, free T3 and total T4, with a significant decrease in serum TSH hormone among women of group I compared to both groups II and III. There was a significant elevation in serum FSH, LH and total testosterone hormone levels in groups I and II associated with a decrease in serum estradiol, prolactin and free testosterone, compared to control group.

Among group I there was a significant negative correlation between serum total $T 3$ and total testosterone hormones and between total T4 and LH hormones. On the other hand, there was a significant positive correlation between serum TSH and estradiol hormone levels in the same group. For group II there was a significant negative correlation between serum thyroid stimulating hormone (TSH) and LH hormone levels.

From these results it could be concluded that impaired thyroid functions plays an intimate role on the hypothalamic-pituitary-ovarian axis reflected as dysfunctional uterine bleeding (DUB).It is highly recommended to add thyroid functions as a routine test in the investigations of all cases of DUB.
\end{abstract}




\section{INTRODUCTION}

Dysfunctional uterine bleeding (DUB) that occurs during the reproductive years of female life and unrelated to structural uterine abnormalities could be related to endocrinal, neurochemical or pharmacological mechanisms ${ }^{(\mathbf{1})}$. Disorders of the hypothalamicpituitary-ovarian axis commonly lead to two presenting complaints: dysfunctional uterine bleeding (DUB) and infertility ${ }^{(2)}$.

Thyroid dysfunction is extremely common in women and has unique consequences related to menstrual cycles and reproduction $^{(3)}$. Both hyper and hypo thyroidism may result in menstrual disturbances. In hyperthyroidism, the most common manifestation is simple oligomenorrhea as well as anovulatory cycles $^{(4)}$. In hypothyroidism, the most common noticed manifestation is oligomenorhea ${ }^{(5)}$. However, heavy menstrual bleeding has, also, been reported with hypothyroidism $^{(6)}$. Galactorrhea may, also, be present in hypothyroidism and may be possibly related to the fact that hypothalamic thyrotropicreleasing hormone, increases the secretion of both TSH and prolactin $(\mathrm{PRL})^{(7)}$. Sex steroid hormone administration and pregnancy have been clearly demonstrated to alter free and total thyroid hormone concentrations $^{(\mathbf{8})}$. The scientific proof of the presence of $\mathrm{TSH}$, as well T3 receptors in the ovaries, has provided a way of direct TSH and T3 effect on steroidogenesis and oocytematuration ${ }^{(9)}$.
The aim of the present study is to evaluate the functional status of thyroid gland in apparently euthyroid women with abnormal menstruation to find the influence and frequency of disturbed thyroid functions on DUB.

\section{PATIENTS \& METHODS}

The present study was conducted on 60 women selected from outpatient Clinic of Gynecology, Kasr El Aini Hospital. All were in the reproductive period with age ranged between 20 and 40 years. According to the pattern of menstrual cycle they were divided into 3 groups:

Group I: Included 20 women with mean age (values \pm S.D) $34.4 \pm 5.54$ years and duration of marriage 13.25 $\pm \quad 7.4$ years. All subjects have functional menorrhagia defined as: Cyclic menstrual bleeding more than $80 \mathrm{~mL}$ of blood or bleeding for more than 7 consecutive days.

Group II: Included 20 women with mean age of (values \pm S.D) $26.5 \pm$ 4.51 years and duration of marriage $6.25 \pm 2.9$ years. All of them have oligo, hypo or oligohypomenorrhea defined when the interval between 2 periods was more than 35 days or when there was more than 20\% decrease in menstrual flow or both together.

Group III: Included 20 women with mean age of (values \pm S.D) $26.5 \pm$ 6.04 years and duration of marriage $5.92 \pm 5.3$ years having normal menstrual cycle (control group).

All members of the study were subjected to: clinical examination including history taking, and vaginal ultrasonography to exclude local 
organic abnormalities. Endometrial biopsy was done for all DUB cases. Diabetic patients were excluded from the study.

The following laboratory investigations were done:

- Full blood picture.

- Determination of serum total T3 and $\mathrm{T} 4^{(\mathbf{1 0})}$ and serum free $\mathrm{T} 4^{(\mathbf{1 1})}$.

- Serum prolactin ${ }^{(12)}, \mathrm{FSH}^{(13)}, \mathrm{LH}^{(\mathbf{1 4})}$.

- Serum Estradiol (E2) ${ }^{(\mathbf{1 5})}$ and progesterone (PRG) ${ }^{(\mathbf{1 6})}$.

- Total serum testosterone ${ }^{(\mathbf{1 2})}$ and free testosterone $^{(\mathbf{1 7})}$.
Statistical analysis:

The statistical analysis and comparison between different groups in the present study were done using analysis of variance (ANOVA) test. Correlation between various variables was done using Pearson moment correlation coefficient (r). Probability value ( $\mathrm{P}$ value) less than 0.05 were considered significant.

All statistical calculations were done using SPSS package ${ }^{(\mathbf{1 8})}$.

\section{RESULTS}

The results of the study are summarized in tables 1-3 and figures 1-4.

Table 1: Serum thyroid hormones profile among the different groups of the study. Values are means \pm S.D.

\begin{tabular}{|c|c|c|c|}
\hline Hormones & $\begin{array}{c}\text { Menorrhagia } \\
(\mathrm{n}=20)\end{array}$ & $\begin{array}{c}\text { Oligohypomenorrhea } \\
(\mathrm{n}=20)\end{array}$ & $\begin{array}{c}\text { Control group } \\
(\mathrm{n}=20)\end{array}$ \\
\hline Total T3(ng/dl) & $288.04 \pm 199.77^{\mathbf{a b}}$ & $150.25 \pm 31.24$ & $127.50 \pm 31.97$ \\
\hline Free T3(pg/dl) & $5.73 \pm 2.18^{\mathbf{a b}}$ & $3.19 \pm 1.22$ & $2.65 \pm 0.66$ \\
\hline Total T4(ug/dl) & $16.47 \pm 5.61^{\text {ab }}$ & $10.64 \pm 1.55$ & $8.02 \pm 2.01$ \\
\hline Free T4(ng/dl) & $1.96 \pm 0.79$ & $1.13 \pm 0.17$ & $1.32 \pm 0.33$ \\
\hline TSH(ulU/ml) & $0.47 \pm 0.49^{\mathbf{a b}}$ & $0.94 \pm 0.48$ & $1.31 \pm 0.93$ \\
\hline
\end{tabular}

a: Significant differences between menorrhagia and oligomenorrhea

b: Significant differences between menorrhagia and controls.

Table 2: Serum FSH;LH and prolactin levels in the different groups of the study. Values are means \pm S.D.

\begin{tabular}{|l|c|c|c|}
\hline \multicolumn{1}{|c|}{ Hormones } & $\begin{array}{c}\text { Menorrhagia } \\
(\mathrm{n}=20)\end{array}$ & $\begin{array}{c}\text { Oligohypomenorrhea } \\
(\mathrm{n}=20)\end{array}$ & $\begin{array}{c}\text { Control group } \\
(\mathrm{n}=20)\end{array}$ \\
\hline FSH(ulU/ml) & $9.02 \pm 5.74^{\mathbf{b}}$ & $7.53 \pm 3.74^{\mathbf{c}}$ & $3.99 \pm 1.37$ \\
\hline LH(ulU/ml) & $7.68 \pm 3.45^{\mathbf{a}}$ & $10.82 \pm 5.41^{\mathbf{c}}$ & $4.68 \pm 2.34$ \\
\hline Prolactin(ng/ml) & $7.58 \pm 2.38^{\text {ab }}$ & $12.13 \pm 12.0$ & $15.18 \pm 5.34$ \\
\hline
\end{tabular}

a: Significant differences between menorrhagia and oligomenorrhea

b: Significant differences between menorrhagia and controls.

c: Significant differences between oligomenorrhea and controls. 
Table 3: Sex hormones profile among the different groups of the study. Values are means \pm S.D.

\begin{tabular}{|l|c|c|c|}
\hline \multicolumn{1}{|c|}{ Hormones } & $\begin{array}{c}\text { Menorrhagia } \\
(\mathrm{n}=20)\end{array}$ & $\begin{array}{c}\text { Oligohypomenorrhea } \\
(\mathrm{n}=20)\end{array}$ & $\begin{array}{c}\text { Control group } \\
(\mathrm{n}=20)\end{array}$ \\
\hline Estradiol $(\mathbf{p g} / \mathbf{m l})$ & $84.24 \pm 44.77^{\mathbf{b}}$ & $93.88 \pm 49.32$ & $121.55 \pm 40.2$ \\
\hline Progesterone $\mathbf{( n g / m l})$ & $9.18 \pm 9.2$ & $6.68 \pm 3.8$ & $7.83 \pm 2.66$ \\
\hline Total testosterone $(\mathbf{n g} / \mathbf{m l})$ & $0.81 \pm 0.15^{\mathbf{b}}$ & $0.78 \pm 0.17^{\mathbf{c}}$ & $0.35 \pm 0.12$ \\
\hline Free testosterone(pg/ml) & $0.44 \pm 024^{\mathbf{b}}$ & $0.42 \pm 0.24^{\mathbf{c}}$ & $1.26 \pm 0.44$ \\
\hline
\end{tabular}

a: Significant differences between menorrhagia and oligomenorrhea

b: Significant differences between menorrhagia and controls.

c: Significant differences between oligomenorrhea and controls.

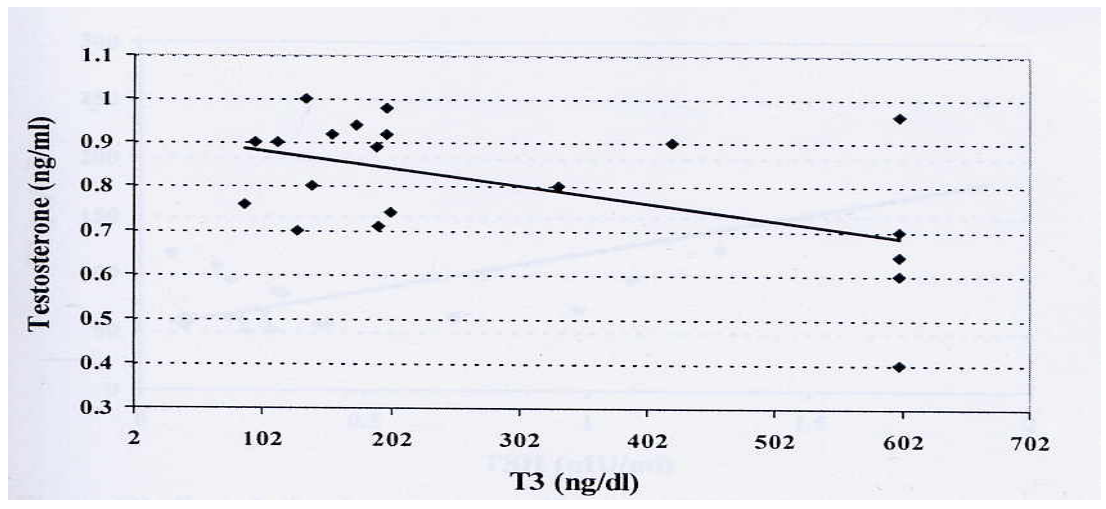

Figure 1: Correlation study between serum T3 and testosterone among 20 cases of menorrhagia $(r=-0.675 \& p<0.05)$.

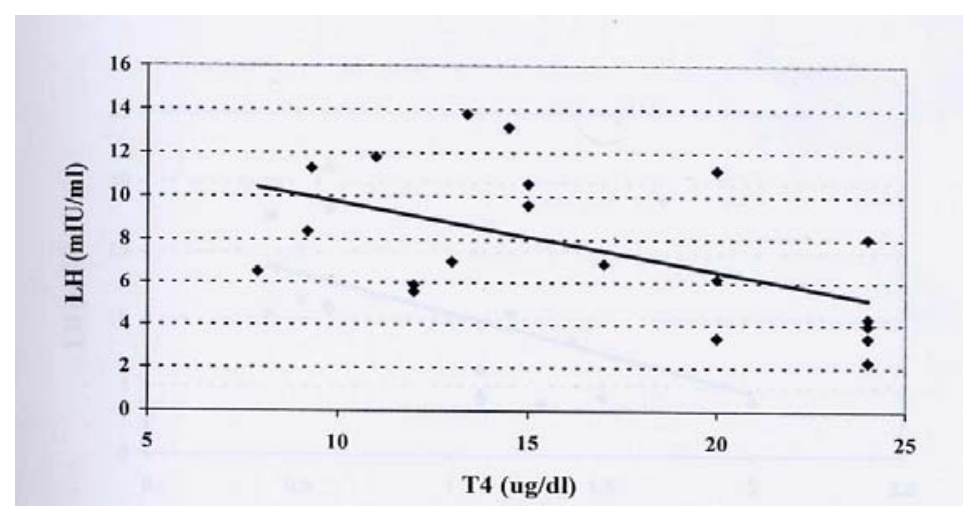

Figure 2: Correlation study between serum T4 and LH among 20 cases of menorrhagia $(r=-0.723 \& p<0.05)$. 


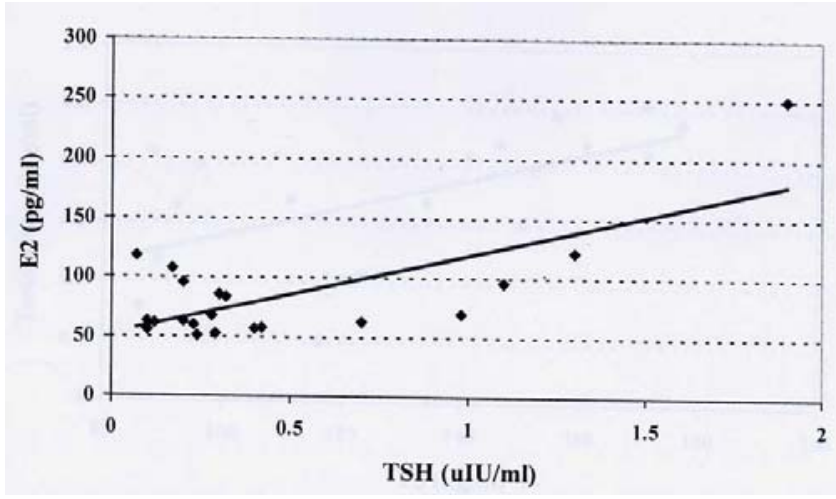

Figure 3: Correlation study between serum TSH and E2 among 20 cases of menorrhagia $(r=0.597 \& p<0.05)$.

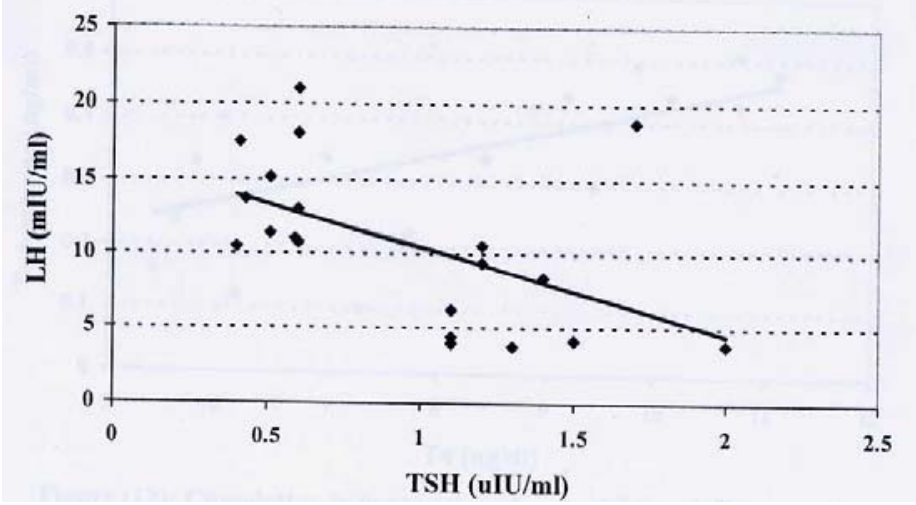

Figure 4: Correlation study between serum TSH and LH among 20 cases of oligohypomenorrhea $(r=-0.791 \& \mathrm{p}<0.05)$.

\section{DISCUSSION}

It is estimated that about one third of all gynecological consultations are carried out for abnormal uterine bleeding. About $80 \%$ of them are due to hormonal disorders, called dysfunctional uterine bleeding (DUB).
The other $20 \%$ are due to organic causes $^{(\mathbf{1 9 )}}$. DUB is defined as uterine bleeding with no demonstrable organic cause either genital or extragenital ${ }^{(20)}$.

Thyroid dysfunction is commonly found in association with DUB and now proved to play a role on 
menstrual cyclicity and reproduction $^{(3)}$. The concept that there are thyroid hormone receptors at the ovaries suggests that thyroid gland may play a regulatory role on the reproductive function. Also, the influence of estrogen on the hypothalamic-pituitary-thyroid axis integrates the reciprocal relationship between these two major endocrine axes $^{(4)}$. Moreover, it was noticed that both hypo and hyperthyroidism are associated with disturbances in menstrual cycle and failure of ovulation $^{(4 \& 5)}$.

The interaction between thyroid function and the clinical disturbance in menstrual cycle has stimulated us to perform the present study to find the relation between thyroid hormone levels and DUB among apparently euthyroid women.

The current results showed that total and free T3, and total T4 were significantly increased in the menorrhagia group while $\mathrm{TSH}$ was significantly decreased compared to the other two groups. On the other hand, free T4 showed a nonsignificant increase regarding the same group. These results reflect the predominance of hyperthyroid status among menorrhagia patients (about $45 \%$ of the subject of menorrhagia group) compared to the oligohypomenorrhea and control groups. Speroff and Fritz ${ }^{(21)}$ stated that the effect of thyroid dysfunction on menstrual cycle is not entirely specific and menstrual changes associated with hyperthyroidism are unpredictable. Also, Krassas ${ }^{(5)}$ stated that menorrhagia occurring with thyroid dysfunction is probably due to estrogen breakthrough bleeding secondary to anovulation.

In the present study, mean serum levels of FSH and LH showed significant increase in groups I and II compared to group III. Also, there was significant negative correlation between serum total T4 and serum LH hormones in group I. These findings are consistent with that observed by Raber et al. ${ }^{\text {(22) }}$ who reported that thyroid hormones play a role in the modulation of LH and FSH mediated control on granulosa cell function. That effect could be either stimulatory $^{(23)}$ or inhibitory ${ }^{(24)}$.

Regarding serum prolactin, the results of the present study showed a significant decrease in menorrhagia group compared to the oligohypomenorrhea and control groups. Yen and Jaffe ${ }^{(25)}$ reported that TRH mediated prolactin release could be modified by hyperthyroidism. The authors explained that correlation by the inhibitory effect of elevated T3 and T4 on PRL-mRNA accumulation and release.

In the present study the mean level of total testosterone showed a significant increase while free testosterone showed significant decrease in group I compared to control group. Also, a significant reduction in serum E2 was detected in group I compared to groups II and controls. A significant negative correlation was found between serum total T3 and total testosterone and a significant positive correlation was noticed between TSH and estradiol in the menorrhagia group.

These finding are concomitant with that of Redmond ${ }^{(3)}$ who found an increase in total testosterone and 
estradiol in cases of hyperthyroidism. He explained these changes by the increased concentration of SHBG with hyperthyroidism, presumably as results of overall changes in hepatic biosynthetic activity. Also, the significant reduction of serum E2 and free testosterone in group I compared to group II could be a result of the increase in SHBG. Tamura et al. ${ }^{(26)}$ reported that thyroid hormones play an inhibitory role on ovarian hormones secretion, which could explain the decrease in E2 level in menorrhagia group.

The elevated FSH level in the present study is most probably due to the relief of feed back inhibition exerted by the low estrogen level that was noticed in groups with menstrual disturbances. The elevated testosterone level could be related to raised LH levels. Also, Weston et al. ${ }^{(27)}$ stated that $\mathrm{LH}$ is known to influence the synthesis of androgens by theca cells.

In the present study serum progesterone level showed a nonsignificant difference among all groups, a finding, also, observed by Doufas and Mastorakos ${ }^{(4)}$ and they contributed that ovulatory menstrual cycles occur in women with thyrotoxicosis in spite of the menstrual disturbances. In the present study, histopathological patterns showed predominance of endometrial hyperplasia among the menorrhagia group which is consistent with what was reported by Evans et al. ${ }^{\mathbf{( 2 8 )}}$ that changes in the uterus could be expected with variation of serum thyroid levels because thyroid hormone receptors have been reported to be present in the uterus.
Conclusion and recommendations:

From the results of the present study it could be concluded that impaired thyroid function plays an intimate role on the hypothalamicpituitary-ovarian-axis and that is reflected as DUB. It is highly recommended to perform thyroid function tests as a routine in all cases of DUB.

\section{REFERENCES}

1. Munro M.G. (2001): Dysfunctional uterine bleeding: Advances in diagnosis and treatment. Curr Opin Obstet Gynecol., 13:475-89.

2. Sillem M.; Rabe T. and Runnebaum B. (1997): Effect of central and ovarian endocrine disturbances on the female genital tract, clinical signs and symptoms. Verh Dtsn Ges Pathol. , 81:191-6.

3. Redmond G.P. (2004): Thyroid dysfunction and women's reproductive health. Thyroid; 14 ., 1:S5-15.

4. Doufas A.G. and Mastorakos G. (2000): The hypothalamicpituitary- thyroid axis and the female reproductive system. Ann NY Acad Sci., 900:65-76.

5. Krassas G.E. (2000): Thyroid disease and female reprodution. Fertil Steril. , 74: 1063-70.

6. Farrell E.(2004): Dysfunctional uterine bleeding. Australian family Physician., 33: 906 - 908.

7. Koutras D.A. (1997): Disturbances of menstruation in thyroid disease Ann NY Acad Sci., 916:280 - 84. 
8. Arafah B.M (2001): Increased need for thyroxin in women with hypothyroidism during estrogen therapy. N EngL J Med., 344: 1743-49.

9. Oravec S. and Hiavacka S. (2000): Disorders of thyroid function and fertility disorders. Ceska Gyanekol. , 65:53-7.

10. Sterling K.; Refetoff S. and Selenkow H.A. (1970): Thyrotoxicosis due to elevated serum triiodothyronine levels, JAMA. , 213:571-5.

11. Burger A.G; Lambert M.J. and Cullen M. (1982): Pharmacological influence on free thyroid hormones.Elsevier Biomedical press,pp. ,303-14

12. Burtis C.A. and Ashwood E.R. (1994): Tietz text book of clinical chemistry $2^{\text {nd }}$, ed. WB Saunders company, Philadelphia, pp. 167581.

13. Massa G.; De Zecher F. and Vander schuren - Lodewy K K. (1992): Serum levels of immuno reactive Inhibin, FSH and $\mathrm{LH}$ in human infants at preterm and term Birth. Biol of the Neonate 61:150-61.

14. Vermes I.; Bonteh A., SluisVeer G. and SchoemaKer J. (1991): interpretations of five monoclonal immunoassays. Lutropin and follitropin: effects of normalization with WHO standard. Clin Chem.,37:415-419.

15. Mehta R.R. (1987): Sub cellular concentrations of estrone, estradiol, androstenedione and 17 .hydroxy steroid dehydrogenase. Activity in malignant and non-malignant human breast tissue. Int Cancer 40:305.8.

16. Hilborn S. and Krahn J. (1987): Effect of time of exposure to gelbarrier tubes on results for progesterone and some other endocrine tests. Clin.Chem., 33:204-10.

17. McCann D. and Kirkish $L$. (1985): Evaluation of free testosterone in serum. J. Clin. Immunoassay. , 8:234-36.

18. Marija J.N. (1985): SPSS/PC for IBM PC/XT/AT.SPSS INC. Chicago. USA.

19. Morano B.; Zarbo R., Puglisi F. and Zarbo G. (2003): Dysfunctional uterine bleeding: medical therapies. Minerve Gynaecol., 55:241-51.

20. Saha B.C. (2003): Recent trend in the treatment of dysfunctional uterine bleeding. J.Indian Med.Assoc., 101: 305-7.

21. Speroff L. and Fritz A.M. (2005): Reproduction and thyroid. Clin. Gynaecol. Endocrinol. Infertile. Lippincott Williams and Wilkins, Baltimore pp., 805-23.

22. Raber W., Nowotny P., Vytiska. Binstorfer E. and Vierhapper H. (2003): Thyroxin treatment modified in fertile women according to thyroxin releasing hormone testing: 5 year follow up of 283 women referred after exclusion of absolute causes of infertility. Human Reprod., 18:707-14.

23. Wakim A.N.; Polizotto S.L.; and Burholt D.R. (1995): Augmentation by thyroxin of human granulose cell gonadotropin-induced 
steroidogenesis. Hum.Reprod. 10: 2845-48.

24. Cecconi S.; Rucci N.; Scaldaferri M.L.; Rossi G.; Moretti C.; D’Armiento M.; and Ulisse S. (1999): Thyroid hormone effect on mouse oocyte maturation and granulose cell aromatase activity. Endocrinology 140:1783-88.

25. Yen S.S.C. and Jaffe R.B. (1999): Prolactin in human reproduction. In: Reproductive Endocrinology. WB Saunders Company, USApp. , 257-84.

26. Tamura K.; Hatsuta M., watanabe G. et al. (1998): Inhibitory regulation of gene expression by thyroid hormone during ovarian development in immature rats. Biochem. Biophys. Res. Commun., 242: 102-8.

27. Weston A.M.;Zelinski-Wooten M.b., Hutchisem J.S. et al. (1996): Development potential of embryos produced by in -vitro fertilization from gonadotrophin releasing hormone antagonist treated macaques stimulated within combination with luteniziing hormone. Hum Reprod., 11:608-13.

28. Evans E.w.; Forwell A.P. and Braver man L.E. (1983): Nuclear thyroid hormone receptors in the rat uterus. Endocrinology 113:1459-63.

\section{الملخص العربي}

أ.د..محمد المليجى (') أ.د.دولت المليجى (r) أ.د. .عبد الحميد عطية (1)

أ .د. .امبمة حسن (r) نعمة حسن (') .د. .احمد الدمبرى (ع) (1)

ا:قسم امرض النساء و التوليب r : قسم الكبياء الحبيةبة ب: قسم الباثولجى بكلبة طب القاهرة

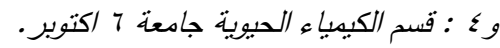

يعد النزيف الرحمي الغير طبيعي واحدا من أكثر مشاكل أمراض النساء شيوعاً، وهو يشمل أب خلل في

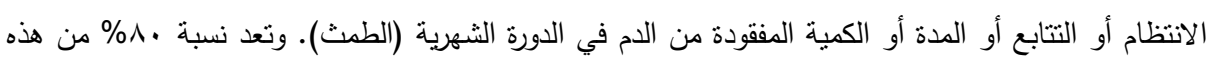

الحالات ناتجة عن اضطرابات هرمونية.

إن خلل وظيفة الغدة الدرقية شائع للغاية بين السيدات وله تبعات فريدة مؤثرة على الدورة الشهرية ويظهر

هذا التأثير على صورة إفراز الهرمونات المحفزة لإفراز الهرمونات التناسلية وعملية الايض المحيطي للهرمونات

الاستيرويدية وعملية الايض لهرمون البرولاكتين.

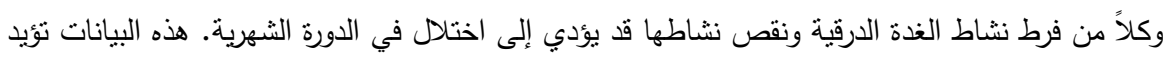

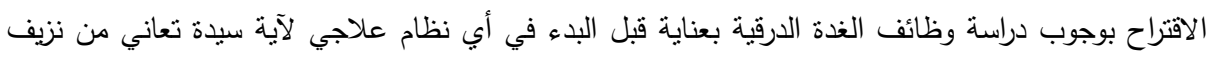

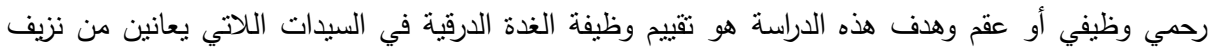


رحمي وظيفي وتبدو لديهن وظيفة الغدة الدرقية طبيعية ظاهريا. هؤلاء السيدات تم تقسيمهن إلى ثلاث مجموعات بناءا على صورة اختلال الدورة الثهرية. المجموعة الأولي : السيدات اللاتي يعانين من زيادة كمية دم الدورة الثهرية أو زيادة عدد أيامها

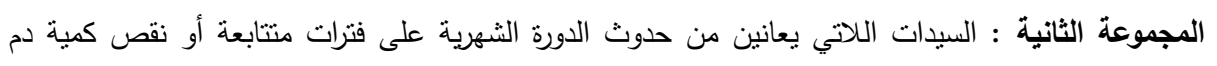
الدورة الثهرية أو كليهما معاً.

المجموعة الثالثة : سيدات لا يعانين من اضطرابات في الدورة الثهرية (المجموعة الضابطة).

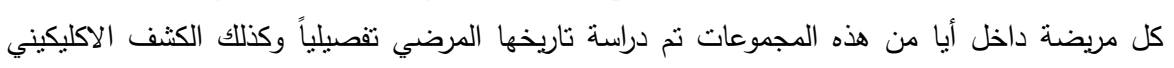

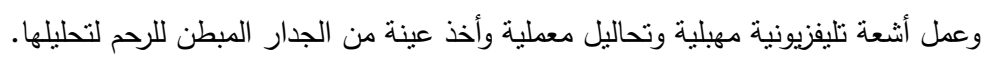

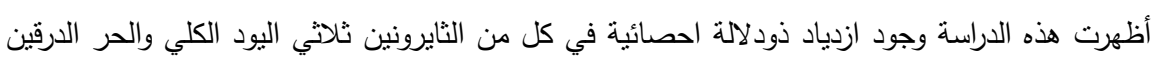

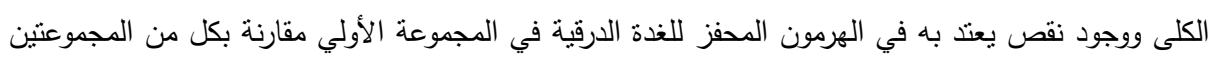
الثانية والثالثة.

كما وجد ازدياد ذودلالة احصائية في هرمونات FH و FSH وهرمون التستوستيرون الكلى في

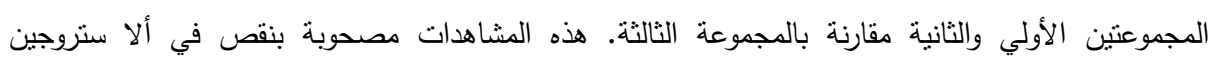

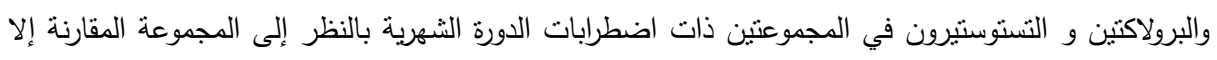
أن هذا النقص ذودلالة احصائية في المجموعة الأولي فقط.

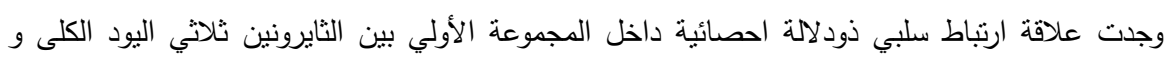

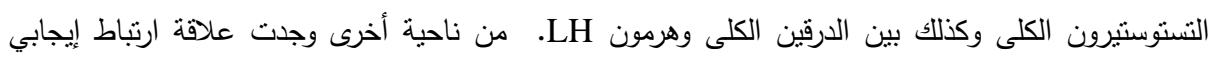

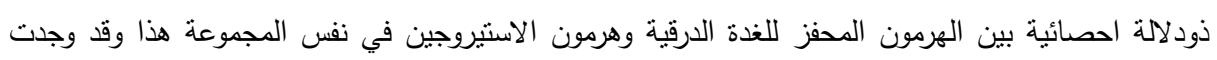

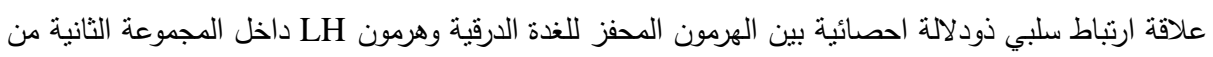

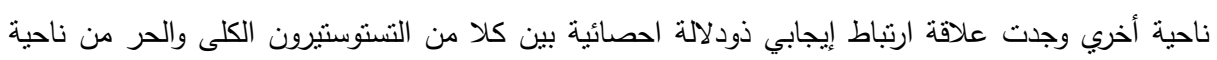

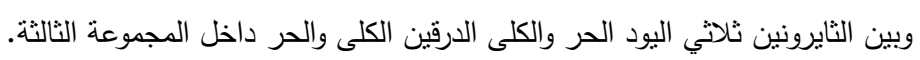

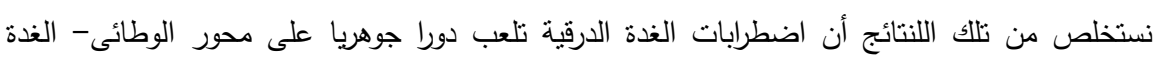

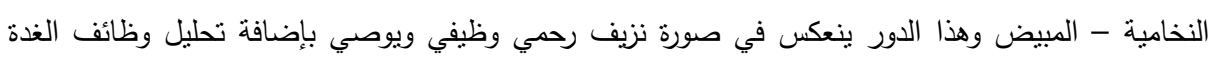
الدرقية كتحاليل روتينية لكل مريضات النزيف الرحمي الوظيفي. 